\author{
Hanna Klimek \\ Janusz Dąbrowski
}

\title{
POLSKIE PORTY MORSKIE NA RYNKACH USŁUG PORTOWYCH
}

\begin{abstract}
Streszczenie
Polskie porty morskie funkcjonują na międzynarodowych rynkach usług portowych charakteryzujących się intensywną konkurencją. Na zapleczu spornym konkurują o ładunki i zainteresowanie przewoźników pomiędzy soba, z portami zagranicznymi (głównie południowego wybrzeża Bałtyku oraz położonymi nad Morzem Północnym), ale także $\mathrm{z}$ transportem lądowym (nawet $\mathrm{w}$ relacjach transkontynentalnych). Konkurencja, w której uczestniczą niewątpliwie przyczynia się do podejmowania działań służących rozwojowi ich potencjału produkcyjnego, rozszerzaniu ich oferty usługowej, podnoszeniu jakości usług, wdrażaniu rozwiązań, które mają przyciagnąć nie tylko załadowców czy przewoźników, ale także inwestorów. Główne polskie porty należą obecnie do największych w Regionie Morza Bałtyckiego. Celem artykułu jest pokazanie ich pozycji konkurencyjnych na krajowym i bałtyckim rynku usług portowych. Realizacja przyjętych przez te porty przed kilku laty strategii ma przyczynić się do podniesienia ich zdolności do konkurowania, a także pozycji konkurencyjnych.

Słowa kluczowe: rynek usług portowych, konkurencyjność portów morskich, udział w rynku.
\end{abstract}

\section{Wstęp}

Morski potencjał Rzeczypospolitej Polskiej jest uwarunkowany bezpośrednim dostępem do Morza Bałtyckiego (długość linii brzegowej wynosi 788 km). Obszary morskie, tj. morskie wody wewnętrzne, morze terytorialne oraz wyłączna strefa ekonomiczna, stanowią ponad $10 \%$ powierzchni lądowej kraju (ich łącz- 
na powierzchnia wynosi 31378 km²). Morze Bałtyckie należy do mórz śródlądowych, charakteryzujących się wysoką intensywnością żeglugi uprawianej przez statki różnego przeznaczenia o coraz większym tonażu. Należy ono do akwenów najbardziej eksploatowanych pod względem transportowym na świecie. Rocznie ok. 400 tys. statków wpływa lub opuszcza Bałtyk, a ok. 2000 jednostek znajduje się równocześnie na morzu. Jest on połączony z Oceanem Światowym i głównymi międzynarodowymi szlakami morskimi przez Cieśniny Duńskie (których średnia głębokość wynosi ok. 17 m), co powoduje, że wymiana wód jest ograniczona i akwen jest szczególnie narażony na zanieczyszczenia, ale także ograniczona jest wielkość wpływających tu statków.

Od końca lat 80. XX wieku polska gospodarka morska podlegała zmianom pod wpływem różnorodnych uwarunkowań zewnętrznych i wewnętrznych. Zmieniło się znaczenie tradycyjnych sektorów gospodarki morskiej i kierunki ich rozwoju. Przy znaczącym współudziale funduszy Unii Europejskiej następuje dynamiczny rozwój portów morskich, wyraźna jest poprawa stanu technicznego infrastruktury drogowej i kolejowej zapewniającej dostęp do portów od strony zaplecza, co zwiększa ich potencjał usługowy i przyczynia się do podnoszenia konkurencyjności. Modernizacja i rozbudowa infrastruktury portowej i zapewniającej dostęp do portów umożliwia integrację polskiej sieci transportowej z transeuropejską siecią transportową TEN-T (Trans-European Network - Transport).

Wśród ok. 17,5 tys. podmiotów gospodarczych funkcjonujących obecnie w gospodarce morskiej Polski ok. 2,4 tys. (ok. 13,77\%) stanowią przedsiębiorstwa związane z obrotem portowo-morskim oraz turystyką morską i przybrzeżną (612 przeładunkowo-składowych, 436 prowadzących działalność wspierającą transport morski, 618 morskich agencji transportowych, 12 zarządów porów, 487 zajmujących się morskim i przybrzeżnym transportem wodnym, 235 zajmujących się turystyką morską i przybrzeżną) (Główny Urząd Statystyczny [GUS], 2018a, s. 34). W przedsiębiorstwach tych jest zatrudnionych ok. 24,2 tys. osób, co stanowi ok. 22,33\% wszystkich zatrudnionych w polskiej gospodarce morskiej (GUS, 2018a, s. 36).

Kluczowe znaczenie dla funkcjonowania i rozwoju całego sektora gospodarki morskiej w Polsce, a także rynków usług portowych, ma Strategia rozwoju transportu do 2020 roku (z perspektywa do 2030 roku), w której transport morski stanowi istotny element zintegrowanego systemu transportowego kraju (co wpisuje się $\mathrm{w}$ zasadniczy nurt polityki transportowej Unii Europejskiej). Wyznaczone w niej kierunki działań koncentrują się na rozwoju infrastruktury w portach morskich i na ich zapleczu, wzmocnieniu funkcji gospodarczych portów oraz zwiększeniu znaczenia żeglugi morskiej w logistycznych łańcuchach dostaw towarów i przewozach pasażerskich. Misją polskiej polityki morskiej jest maksymalizacja wszechstronnych korzyści dla obywateli i gospodarki narodowej płynących ze zrównoważonego wykorzystania nadmorskiego położenia kraju oraz zasobów 
mórz i oceanów (Międzyresortowy Zespół do spraw Polityki Morskiej Rzeczypospolitej Polskiej, 2015, s. 12). Wśród kierunków polskiej polityki morskiej priorytetowe znaczenie mają: wzmocnienie pozycji polskich portów morskich, zwiększenie konkurencyjności transportu morskiego oraz zapewnienie bezpieczeństwa morskiego (Międzyresortowy Zespół do spraw Polityki Morskiej Rzeczypospolitej Polskiej, 2015, s. 13).

Dokumentem o charakterze operacyjno-wdrożeniowym, uwzględniającym nie tylko cele Strategii rozwoju transportu do 2020 roku (z perspektywą do 2030 roku) (Uchwała Nr 6 Rady Ministrów, 2013) i kierunki Polityki morskiej Rzeczypospolitej Polskiej do roku 2020 (z perspektywą do 2030 roku), ale także cele Strategii na rzecz odpowiedzialnego rozwoju do roku $2020 \mathrm{z}$ perspektywą do $2030 \mathrm{r}$. (Uchwała nr 8 Rady Ministrów, 2017) w odniesieniu do problematyki rozwoju portów morskich jest Program rozwoju polskich portów morskich do roku 2020 (z perspektywą do 2030 roku) (Ministerstwo Gospodarki Morskiej i Żeglugi Śródlądowej [MGMiŻŚ], 20170). Program ten ma stanowić również ramy dla finansowania inwestycji infrastrukturalnych $\mathrm{w}$ polskich portach morskich oraz w zakresie dostępu do tych portów od strony morza i od strony lądu w perspektywie finansowej na lata 2014-2020.

\section{Funkcjonowanie portów morskich w Polsce}

W Polsce funkcjonuje obecnie ponad 60 portów i przystani morskich, charakteryzujących się różną wielkością i złożonością pełnionych funkcji. Na począt$\mathrm{ku}$ lat $90 . \mathrm{XX}$ wieku, wraz z rozpoczęciem zmian politycznych i gospodarczych $\mathrm{w}$ Polsce, w portach rozpoczęły się działania restrukturyzacyjne, które doprowadziły do zmiany systemu zarządzania nimi, przekształcając je z portów funkcjonujących zgodnie $\mathrm{z}$ zasadami państwowego (centralnego) systemu zarządzania $\mathrm{w}$ porty działające na zasadach zbliżonych do stosowanych $\mathrm{w}$ wielu portach krajów o gospodarce rynkowej. Działalność administracyjną oddzielono od działalności eksploatacyjnej. Ta pierwsza stała się domeną zarządów portów (nowo powstałych spółek akcyjnych, w których współwłaścicielami są Skarb Państwa, gminy, na terenach których leżą porty, i inne podmioty), zaś działalność usługowa na rzecz gestorów ładunków, armatorów i pasażerów pozostała w gestii spółek działających w sferze eksploatacji (wiele spośród obecnie funkcjonujących przedsiębiorstw usługowych, dawniej pozostających częścią państwowych przedsiębiorstw portowych, zostało sprywatyzowanych i działa dziś jako spółki akcyjne lub z ograniczoną odpowiedzialnością, należąc do kapitału krajowego lub zagranicznego).

Zasady zarządzania portami morskimi w Polsce określa Ustawa $z$ dnia 20 grudnia 1996 r. o portach i przystaniach morskich (Dz. U. z 2010 r. Nr 33, poz. 179, z późn. zm.). Zgodnie z nią cztery porty mają podstawowe znaczenie dla gospodarki narodowej i są to porty w Gdańsku, Gdyni, Szczecinie i Świnoujściu. Za- 
rządzane są one przez 3 spółki, będące tzw. podmiotami zarządzającymi w myśl przywołanej wyżej ustawy (odpowiednio: Zarząd Morskiego Portu Gdańsk SA, Zarząd Morskiego Portu Gdynia SA i Zarząd Morskich Portów Szczecin i Świnoujście SA). Porty te są ważnymi ogniwami transeuropejskiej bazowej sieci transportowej TEN-T w korytarzu Bałtyk-Adriatyk. Poza czterema największymi, w Polsce funkcjonuje jeszcze 29 portów niemających podstawowego znaczenia dla gospodarki narodowej (największymi wśród nich są porty w Policach, Darłowie, Kołobrzegu, Elblągu, Ustce) oraz 33 przystanie morskie (przystanie rybackie) (Ministerstwo Transportu, Budownictwa i Gospodarki Morskiej [MTBiGM], 2013, s. 26). Na terenach położonych $\mathrm{w}$ granicach administracyjnych portów funkcjonują ośrodki usługowe skupiające, poza podmiotami zarządzającymi (będącymi przedsiębiorstwami o profilu użyteczności publicznej), wiele różnej wielkości przedsiębiorstw świadczących usługi w sferze eksploatacji. Podstawową zasadą nadal pozostaje oddzielenie funkcji zarządzania terenami i infrastrukturą $\mathrm{w}$ portach (przypisanej podmiotom zarządzającym) od prowadzonej w nich działalności eksploatacyjnej (przypisanej przedsiębiorstwom usługowym). Wszystkie porty pełniące funkcję transportową i handlową posiadają wspólne krajowe zaplecze.

Polskie porty dysponują obecnie potencjałem umożliwiającym obsługę ok. $179 \mathrm{mln}$ ton ładunków rocznie. Największe z nich są portami uniwersalnymi. Mogą obsługiwać różnorodne rodzaje ładunków zarówno masowych (suchych i płynnych), jak i drobnicowych (zjednostkowanych i konwencjonalnych) oraz wyspecjalizowane w przewozach tych ładunków statki (w Gdańsku, Gdyni i Świnoujściu mogą być obsługiwane statki oceaniczne, w tym w Gdańsku największe jednostki, jakie wpływają na Bałtyk). W ostatnich latach potencjał tych portów był wykorzystywany w ok. 50\% (w 2017 roku obsłużyły łącznie ok. 90 mln ton ładunków; ok. $97 \%$ tej masy przeładowano w 4 portach o podstawowym znaczeniu dla gospodarki narodowej). Rozmiary potencjału usługowego zmieniają się w czasie w związku z działalnością inwestycyjną portów, natomiast stopień wykorzystania tego potencjału zależy od rozmiarów popytu zgłaszanego przez krajowych i zagranicznych usługobiorców. Porty utrzymują regularne bezpośrednie połączenia żeglugowe zarówno z portami Regionu Morza Bałtyckiego i Morza Północnego, jak i innymi, w tym port gdański obsługuje bezpośrednie połączenie transkontynentalne z portami Azji Południowo-Wschodniej, wykonywane przez największe kontenerowce świata. Wszystkie porty obsługują corocznie ok. 30\% ładunków polskiego handlu zagranicznego (MGMiŻŚ, 2017, s. 13).

Największe porty realizują ambitne programy inwestycyjne umożliwiające zwiększenie ich potencjału usługowego, co ma prowadzić do podniesienia ich konkurencyjności na bałtyckich rynkach usług portowych (do najważniejszych planowanych inwestycji należą te związane z poprawą stanu infrastruktury portowej i zapewniającej dostęp do portów, polegające zwłaszcza na pogłębianiu 
akwenów, odnawianiu zdekapitalizowanych nabrzeży portowych, a także te, które polegają na budowie nowoczesnych terminali wychodzących $\mathrm{w}$ morze, wykorzystujących duże naturalne głębokości blisko brzegu) (Klimek, 2018). Optymistyczne prognozy rozwoju obrotu portowo-morskiego, zwłaszcza ładunkami skonteneryzowanymi (UNCTAD, 2018, s. 16], skłaniają podmioty zarządzające portami do poszukiwania inwestorów zewnętrznych, a także sięgania po dofinansowanie projektów inwestycyjnych ze środków Unii Europejskiej. Wśród planowanych lub realizowanych inwestycji portowych są także takie, które służą dostosowaniu portów do wymogów ochrony środowiska naturalnego (np. związane z zaopatrywaniem statków $\mathrm{w}$ portach $\mathrm{w}$ paliwo LNG lub zasilanie statków prądem elektrycznym $z$ brzegu). W portach podejmuje się też inwestycje związane z obsługą ruchu pasażerskiego (promowego i wycieczkowego).

\section{Polskie porty morskie na krajowym rynku usług portowych}

Jednym z podstawowych mierników oceny aktywności gospodarczej portów morskich (służącym ustaleniu ich pozycji konkurencyjnej) jest wolumen obsłużonych ładunków, traktowany jako masa brutto, a więc masa własna ładunku wraz z opakowaniem, lecz z wyłączeniem (od 2004 r.) masy własnej jednostki ładunkowej (kontenera) i jednostek tocznych. Szczególnie dynamiczny wzrost przeładunków w portach morskich w Polsce jest obserwowany od 2010 roku. Średniorocznie w latach 2010-2017 przeładunki ogółem zwiększały się o ok. 6\%. Wolumen przeładunków $\mathrm{w}$ najważniejszych polskich portach, $\mathrm{z}$ uwzględnieniem grup rodzajowych ładunków, przedstawiono w tabelach 1 i 2.

W 2017 roku krajowy obrót morski stanowił 3,2\% obrotów portowych, zaś 96,8\% ładunków polskie porty obsłużyły w obrocie międzynarodowym (w tym ok. $13 \mathrm{mln}$ ton stanowiły ładunki tranzytowe; głównymi krajami tranzytowymi dla polskich portów są Czechy, 30,9\%, i Rosja, 24,8\% wszystkich obsłużonych ładunków tranzytowych). Należy dodać, że w 2017 roku do polskich portów zawinęło 19,5 tys. statków (GUS, 2018b, s. 8). Statki należące do polskich armatorów w relacjach z polskimi portami morskimi przewiozły łącznie 7079,5 tys. ton różnych ładunków (do polskich portów przywiozły 3504,35 tys. ton, z polskich portów wywiozły 3575,14 tys. ton), pomiędzy obcymi portami 988,8 tys. ton, pomiędzy polskimi portami 134,2 tys. ton i 51,3 tys. ton wewnątrz portów (GUS, 2018b, s. 2-4).

Na krajowym rynku usług portowych największym portem morskim jest obecnie port w Gdańsku. W 2017 roku obsłużył ponad 40,613 mln ton różnorodnych ładunków (uwzględniając przeładunki ogółem, na krajowym rynku usług portowych zajął 1 . pozycję, uzyskując wskaźnik udziału w tym rynku na poziomie $45,36 \%$, zaś w rynku portów o podstawowym znaczeniu dla gospodarki narodowej wskaźnik na poziomie 46,54\%; wcześniej wspomniano, że cztery największe krajowe porty, czyli te o podstawowym znaczeniu dla gospodarki 
narodowej, w 2017 roku osiągnęły łącznie udział w krajowym rynku usług portowych na poziomie 97,46\%). Wśród przeładowanych w Gdańsku ładunków $32,42 \%$ stanowiły paliwa płynne, $23,13 \%$ ładunki masowe suche, zaś $44,45 \%$ ładunki drobnicowe. W porcie przeładowano 1593760 TEU. Należy podkreślić, że port zajął 1. pozycję na krajowym rynku usług portowych $\mathrm{w}$ zakresie obsługi ładunków płynnych (z udziałem 71,7\%), 1. pozycję w zakresie obsługi ładunków masowych suchych $(36,82 \%), 1$. pozycję w zakresie obsługi ładunków drobnicowych $(41,61 \%)$, a także 1 . pozycję w zakresie obsługi ładunków skonteneryzowanych $(66,46 \%)$.

Drugą pozycję na krajowym rynku usług portowych (uwzględniając przeładunki ogółem na poziomie 25,4236 mln ton) w 2017 roku zajął zespół portów w Szczecinie i Świnoujściu (których przeładunki podawane są łącznie), uzyskując udział w rynku na poziomie $28,39 \%$ (wskaźnik udziału w rynku portów o podstawowym znaczeniu dla gospodarki narodowej dla tych portów wyniósł 29,13\%). Wśród przeładowanych w portach Szczecina i Świnoujścia ładunków największy udział miały ładunki drobnicowe (50,62\%), 36,09\% przeładowano ładunków masowych suchych i 13,29\% ładunków masowych płynnych. W obu portach przeładowano niewiele kontenerów (93 579 TEU), ale najwięcej spośród krajowych portów ładunków w technologii ro-ro (ponad 6,32 mln ton). Zespół portów zajął 2. pozycję na krajowym rynku usług portowych na rzecz ładunków masowych płynnych (osiągając wskaźnik udziału w rynku na poziomie 18,39\%), 2. pozycję na krajowym rynku usług portowych na rzecz ładunków masowych suchych (z udziałem $w$ rynku na poziomie 35,96\%), 2. pozycję na krajowym rynku usług portowych na rzecz ładunków drobnicowych (z udziałem w rynku na poziomie $29,67 \%$ ) i 3 . pozycję na krajowym rynku usług portowych na rzecz ładunków skonteneryzowanych (z udziałem w rynku na poziomie 3,9\%).

Port morski w Gdyni w 2017 roku zajął 3. pozycję na krajowym rynku usług portowych (uwzględniając przeładunki ogółem), przeładowując 21,225 mln ton różnych ładunków (wskaźnik udziału gdyńskiego portu w krajowym rynku usług portowych wyniósł $23,7 \%$, zaś wskaźnik udziału w rynku portów o podstawowym znaczeniu dla gospodarki narodowej wyniósł 24,32\%). Wśród przeładowanych w Gdyni w 2017 roku ładunków 58,71\% stanowiły ładunki drobnicowe, 32,72\% ładunki masowe suche, zaś 8,57\% ładunki masowe płynne. Port w Gdyni zajął 3. pozycję w krajowym rynku usług portowych na rzecz ładunków masowych płynnych (osiągając wskaźnik udziału w rynku na poziomie 9,91\%), 3 . pozycję $\mathrm{w}$ krajowym rynku usług portowych na rzecz ładunków masowych suchych (osiaggając wskaźnik udziału w rynku na poziomie $27,22 \%$ ) oraz 3 . pozycję w krajowym rynku usług portowych na rzecz ładunków drobnicowych (osiagając wskaźnik udziału w rynku na poziomie $28,72 \%$ ). Gdyński port osiagnął natomiast 2. pozycję w krajowym rynku usług portowych na rzecz ładunków skonteneryzowanych (osiagając wskaźnik udziału w rynku na poziomie 29,64\%). 
Pozostałe polskie porty morskie (te, które nie mają podstawowego znaczenia dla gospodarki narodowej) przeładowały w 2017 roku łącznie 2,277 mln ton różnych ładunków (były to głównie ładunki masowe suche). Największym wśród nich jest port w Policach, w którym obsłużono 1,8698 mln ton ładunków (wskaźnik jego udziału w krajowym rynku usług portowych wyniósł 2,09\%), 2. lokatę wśród mniejszych portów zajął port w Kołobrzegu (wskaźnik jego udziału w krajowym rynku usług portowych wyniósł 0,22\%), trzecią zaś port w Darłowie (wskaźnik jego udziału w krajowym rynku usług portowych wyniósł 0,12\%), a czwartą port w Elblagu (wskaźnik jego udziału w krajowym rynku usług portowych wyniósł $0,11 \%$ ). W usteckim porcie w 2017 roku nie przeładowywano ładunków.

Tabela 1. Przeładunki w polskich portach morskich o podstawowym znaczeniu dla gospodarki narodowej w latach 2000-2017

\begin{tabular}{|c|c|c|c|c|c|}
\hline Port/ładunek & $\begin{array}{l}\text { Ladunki } \\
\text { masowe } \\
\text { suche } \\
\text { [tys. ton] }\end{array}$ & $\begin{array}{c}\text { Ladunki } \\
\text { masowe } \\
\text { płynne } \\
\text { [tys. ton] }\end{array}$ & $\begin{array}{l}\text { Drobnica } \\
\text { [tys. ton] }\end{array}$ & $\begin{array}{c}\text { w tym kontenery } \\
\text { [TEU] }\end{array}$ & $\begin{array}{c}\text { Razem } \\
\text { [tys. ton] }\end{array}$ \\
\hline \multicolumn{6}{|l|}{ GDAŃSK } \\
\hline 2000 & 9025,5 & 5913,3 & 1773,1 & 14877 & 16711,9 \\
\hline 2005 & 9569,81 & 11903,91 & 1867,28 & 69100 & 23341 \\
\hline 2010 & 6648,8 & 14401,2 & 6132 & 511876 & 27182 \\
\hline 2011 & 7617,1 & 10387,9 & 7300,5 & 685643 & 25305,5 \\
\hline 2012 & 7269,1 & 10741 & 8888 & 928691 & 26898,1 \\
\hline 2013 & 8719,1 & 11026,3 & 10513,9 & 1177279 & 30259,3 \\
\hline 2014 & 8564,7 & 12483,2 & 11229,7 & 1211332 & 32277,6 \\
\hline 2015 & 9388,9 & 14710,5 & 11814,2 & 1085841 & 35913,6 \\
\hline 2016 & 9931,4 & 12808,5 & 14549,1 & 1298352 & 37289 \\
\hline 2017 & 9393,4 & 13168,2 & 18052,2 & 1593760 & 40613,8 \\
\hline \multicolumn{6}{|l|}{ GDYNIA } \\
\hline 2000 & 3885,3 & 271,5 & 4239,7 & 188403 & 8396,5 \\
\hline 2005 & 4251 & 374 & 7605 & 395757 & 12230 \\
\hline 2010 & 5659 & 916 & 8160 & 485255 & 14735 \\
\hline 2011 & 5758,7 & 590,5 & 9562,2 & 616439 & 15911,4 \\
\hline 2012 & 5677,2 & 212,8 & 9919,7 & 676349 & 15809,7 \\
\hline 2013 & 6543,8 & 61,6 & 11053,3 & 729607 & 17658,7 \\
\hline 2014 & 6486,3 & 229,4 & 12693 & 849123 & 19405 \\
\hline 2015 & 6516,8 & 401,9 & 11279,2 & 684796 & 18197,9 \\
\hline 2016 & 6746,3 & 1324,4 & 11465,5 & 642195 & 19536,2 \\
\hline 2017 & 6945,4 & 1819,1 & 12460,4 & 710698 & 21225,2 \\
\hline
\end{tabular}




\begin{tabular}{|l|r|r|r|r|r|}
\hline SZCZECIN & & & & & \\
2000 & & & & & \\
2005 & 12745,8 & 73,3 & 2745,8 & 21860 & 15564,9 \\
2010 & 10777,9 & 0 & 5302,5 & 36453 & 16080,4 \\
2011 & 11335,5 & 1040,2 & 8467,1 & 56503 & 20842,8 \\
2012 & 10666,1 & 1401,5 & 9290,7 & 55098 & 21354,1 \\
2013 & 10438,2 & 1403 & 9425,5 & 52163 & 21266,7 \\
2014 & 11737 & 1620,8 & 9392,2 & 62307 & 22750 \\
2015 & 11393,9 & 1670,3 & 10337,2 & 78439 & 23401,4 \\
2016 & 10180,9 & 1738,9 & 11254,6 & 87784 & 23174,4 \\
2017 & 9461,5 & 2302,2 & 12349,3 & 90869 & 24113 \\
\hline
\end{tabular}

Źródło: Opracowanie własne na podstawie materiałów wewnętrznych portów morskich będących portami o podstawowym znaczeniu dla gospodarki narodowej (www.portgdansk.pl; www.port.gdynia.pl; www.portszczecin.pl).

Tabela 2. Przeładunki w portach morskich w Polsce w latach 2000-2017 [tys. ton]

\begin{tabular}{|c|c|c|r|r|r|r|}
\hline Rok & $\begin{array}{c}\text { Gdańsk, } \\
\text { Gdynia, } \\
\text { Szczecin i } \\
\text { Świnoujście }\end{array}$ & Police & Elbląg & Darłowo & Ustka & Kołobrzeg \\
\hline 2000 & 40673,3 & 2481,4 & 36,4 & 27,0 & 16,9 & 116,4 \\
\hline 2005 & 52537,4 & 2619,4 & 126,8 & 29,0 & 2,7 & 164,3 \\
\hline 2010 & 58918,8 & 1954,0 & 64,8 & 44,0 & 1,9 & 131,4 \\
\hline 2011 & 62571,0 & 2084,0 & 113,5 & 71,3 & 1,5 & 186,6 \\
\hline 2012 & 63973,5 & 1718,3 & 168,5 & 177,0 & 14,1 & 172,6 \\
\hline 2013 & 70668,0 & 1464,6 & 285,5 & 107,0 & 2,7 & 119,3 \\
\hline 2014 & 75088,3 & 1750,9 & 358,3 & 113,1 & 1,7 & 134,3 \\
\hline 2015 & 77285,9 & 1788,0 & 206,9 & 336,7 & 0,2 & 107,8 \\
\hline 2016 & 80938,2 & 1855,1 & 139,5 & 92,4 & 0 & 131,6 \\
\hline 2017 & 87262,6 & 1869,8 & 99,1 & 107,41 & 0 & 200,75 \\
\hline
\end{tabular}

Źródło: Opracowanie własne na podstawie materiałów wewnętrznych portów morskich niebędących portami o podstawowym znaczeniu dla gospodarki narodowej (porty w Policach, Elblagu, Darłowie, Ustce i Kołobrzegu) oraz materiałów wewnętrznych Zarządu Morskiego Portu Gdańsk, Zarządu Morskiego Portu Gdynia SA; Zarządu Morskich Portów Szczecin i Świnoujście SA (www.portgdansk.pl; www.port.gdynia.pl; www.portszczecin.pl). 
Łączna wielkość obrotów ładunkowych polskich portów morskich w latach 2000-2017 została przedstawiona na rysunku 1.

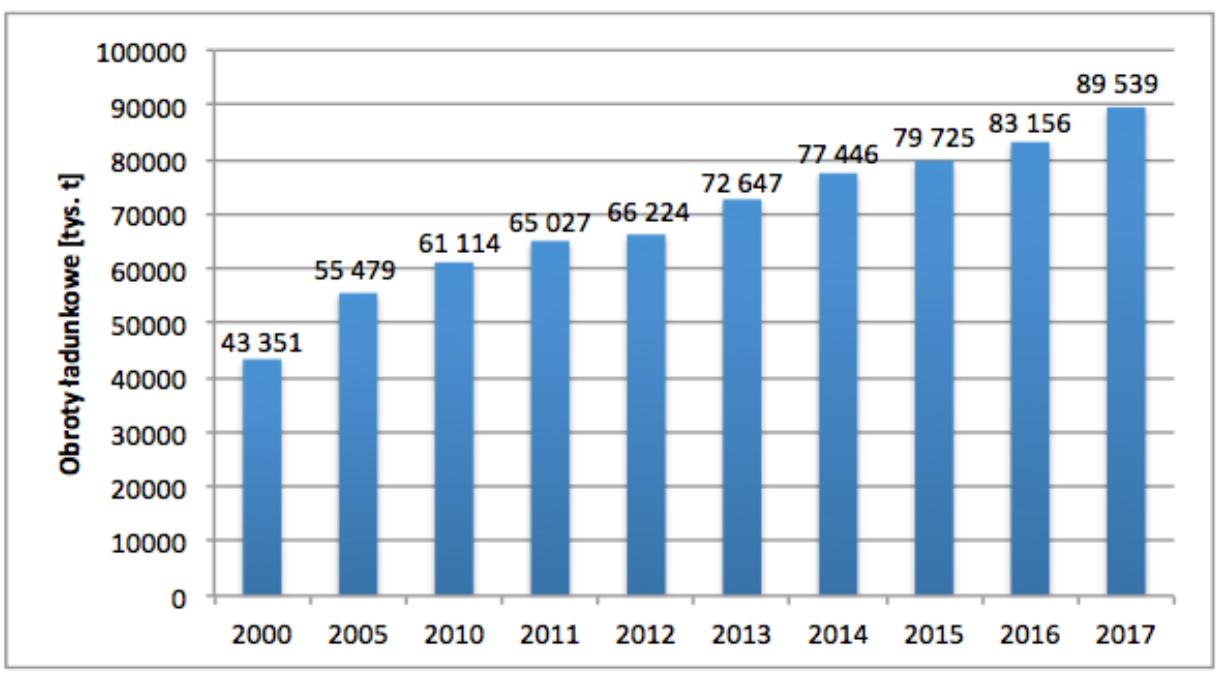

Rysunek 1. Obroty ładunkowe polskich portów morskich w latach 2000-2017 [tys. ton]

Źródło: Opracowanie własne na podstawie materiałów wewnętrznych portów morskich niebędących portami o podstawowym znaczeniu dla gospodarki narodowej (porty w Policach, Elblągu, Darłowie, Ustce i Kołobrzegu) oraz materiałów wewnętrznych Zarządu Morskiego Portu Gdańsk, Zarządu Morskiego Portu Gdynia SA; Zarządu Morskich Portów Szczecin i Świnoujście SA (www.portgdansk.pl; www.port.gdynia.pl; www.portszczecin.pl).

Analiza wolumenu przeładunków polskich portów morskich pokazuje, że w długim okresie występuje tendencja do jego wzrostu. Wyniki przeładunkowe osiaggane przez porty o podstawowym znaczeniu dla polskiej gospodarki świadczą o tym, że ranga tych portów w obsłudze międzynarodowej wymiany towarowej jest coraz wyższa. Co prawda ich znaczenie na globalnych rynkach usług portowych jest niewielkie, ale są to porty o znaczeniu regionalnym, należące do największych w Regionie Morza Bałtyckiego.

\section{Polskie porty morskie na bałtyckim rynku usług portowych}

W 2017 roku port w Gdańsku, według „Baltic Transport Journal”, zajął 6. pozycję, porty w Szczecinie i Świnoujściu 9., zaś port w Gdyni 14. wśród największych portów w Regionie Morza Bałtyckiego. Trzeba jednak zauważyć, że dane statystyczne dotyczące przeładunków dokonanych w polskich portach morskich, opublikowane przez to czasopismo (Baltic yearbook 2017/2018, 2018, s. 174-177), znacznie różnią się od danych podanych na stronach internetowych i w oficjalnych materiałach reklamowych tych portów (różnice dotyczą także niektórych 
innych portów $\mathrm{w} R \mathrm{RB}$, ale nie są tak znaczące, bowiem $\mathrm{w}$ przypadku portu w Gdańsku różnica wynosi 6,608 mln ton na niekorzyść portu, w przypadku portów w Szczecinie i Świnoujściu, których wyniki przeładunkowe publikowane są łącznie, różnica wynosi 1,97 mln ton, zaś w przypadku portu w Gdyni różnica wynosi 2,563 $\mathrm{mln}$ ton na niekorzyść tych portów). Porównanie danych publikowanych na stronach internetowych i w oficjalnych materiałach portów z danymi o przeładunkach $\mathrm{w}$ innych portach bałtyckich prowadzi do wniosku, że co prawda port w Gdańsku zajął w 2017 roku 6. pozycję w RMB, ale zespół portów w Szczecinie i Świnoujściu zajął pozycję 8., a nie 9., jak podaje BTJ, zaś port w Gdyni pozycję 10., a nie 14., jak podaje BTJ.

Wprawdzie w RMB funkcjonuje ponad 400 portów morskich, ale w 2017 roku tylko 93 z nich przeładowały ponad $1 \mathrm{mln}$ ton ładunków, a wśród nich było 21 portów o przeładunkach powyżej $10 \mathrm{mln}$ ton, a zatem największe polskie porty znajdują się w czołówce portów bałtyckich (Baltic yearbook 2017/2018, 2018, s. 174-177). „Baltic Transport Journal” podaje, że w 2017 roku nadbałtyckie porty morskie przeładowały łącznie ok. $910 \mathrm{mln}$ ton ładunków (o 3,2\% więcej niż w 2016 roku) oraz obsłużyły ok. $113 \mathrm{mln}$ pasażerów (Baltic yearbook 2017/2018, 2018, s. 174-177). Około 68\% tych przeładunków dokonano (w 2017 roku) w 20 największych portach regionu. Największy bałtycki port (w Ust Łudze) osiągnął przeładunki na poziomie 103,3 $\mathrm{mln}$ ton (po raz pierwszy w RMB przekraczając wolumen $100 \mathrm{mln}$ ton) (Baltic yearbook 2017/2018, 2018, s. 13]. Przeładunki w największych portach RMB w 2017 roku przedstawia tabela 3. Największych przeładunków w regionie dokonują łącznie porty skandynawskie $(41,7 \%)$, rosyjskie $(27,22 \%)$, polskie $(9,85 \%)$, łotewskie $(6,8 \%)$ oraz niemieckie położone w RMB (ok. 6\%) (Baltic yearbook 2017/2018, 2018, s. 15).

Tabela 3. Przeładunki w największych bałtyckich portach morskich w 2017 roku

\begin{tabular}{|l|l|r|r|r|r|r|}
\hline Lp. & \multicolumn{1}{|c|}{ Port } & $\begin{array}{c}\text { Razem } \\
\text { [tys. ton] }\end{array}$ & $\begin{array}{l}\text { Ladunki } \\
\text { masowe } \\
\text { suche } \\
\text { [tys. ton] }\end{array}$ & $\begin{array}{c}\text { Ladunki } \\
\text { masowe } \\
\text { płynne } \\
\text { [tys. ton] }\end{array}$ & $\begin{array}{r}\text { Drobnica } \\
\text { [tys. ton] }\end{array}$ & $\begin{array}{r}\text { w tym } \\
\text { kontenery } \\
\text { [tys. TEU] }\end{array}$ \\
\hline 1. & Ust Ługa & 103,294 & 36,137 & 63,879 & 3,278 & 72,758 \\
2. & Primorsk & 57,607 & 0 & 57,607 & 0 & 0 \\
3. & St. Petersburg & 53,649 & 9,139 & 7,399 & 37,111 & 1920,65 \\
4. & Kłajpeda & 43,17 & 19,113 & 10,676 & 13,274 & 472 \\
5. & Goeteborg & 40,8 & 0,607 & 23,281 & 16,912 & 644 \\
$\mathbf{6 .}$ & Gdańsk & $\mathbf{4 0 , 6 1 3}$ & $\mathbf{9 , 3 9 4}$ & $\mathbf{1 3 , 1 6 8}$ & $\mathbf{1 8 , 0 5 2}$ & $\mathbf{1 5 9 3 , 7 6}$ \\
7. & Ryga & 33,674 & 20,915 & 5,729 & 7,03 & 489,67 \\
$\mathbf{8 .}$ & Szczecin-Świnoujście & $\mathbf{2 5 , 4 2 3}$ & $\mathbf{9 , 1 7 5}$ & $\mathbf{3 , 3 7 7}$ & $\mathbf{1 2 , 8 7}$ & $\mathbf{9 3 , 5 7 9}$ \\
9. & Skoeldvik & $\mathbf{2 4 , 7 9 3 8}$ & 0 & 24,7938 & 0 & 0 \\
$\mathbf{1 0 .}$ & Gdynia & $\mathbf{2 1 , 2 2 5}$ & $\mathbf{6 , 9 4 4}$ & $\mathbf{1 , 8 1 9}$ & $\mathbf{1 2 , 4 6}$ & $\mathbf{7 1 0 , 6 9 8}$ \\
\hline
\end{tabular}




\begin{tabular}{|l|l|r|r|r|r|r|}
\hline 11. & Rostok & 20,427 & 7,437 & 3,5 & 9,49 & 0 \\
12. & Brofjorgen & 20,4 & 0 & 20,4 & 0 & 0 \\
13. & Ventspils & 19,98 & 6,8 & 10,639 & 2,511 & 0 \\
14. & Tallin & 19,2 & 3,958 & 7,223 & 8,019 & 215,451 \\
15. & Vysotsk & 17,551 & 7,129 & 10,422 & 0 & 0 \\
16. & Lubeka-Travemünde & 16,201 & 1,1 & 0 & $15,1^{*}$ & 90 \\
17. & Kopenhaga-Malmoe & 15,5 & 3,5 & 5,2 & 6,8 & 182,633 \\
18. & HaminaKotka & 14,664 & 3,105 & 2,297 & 9,262 & 687 \\
19. & Helsinki & 14,3 & 2,074 & 0,147 & 12,079 & 490,984 \\
20. & Kaliningrad & 13,884 & 6,818 & 3,108 & 3,958 & 124,971 \\
\hline X & Razem & 616,3558 & 153,345 & 274,6648 & 188,206 & 7788,154 \\
\hline
\end{tabular}

Źródło: (Baltic yearbook 2017/2018, 2018, s. 15; www.haminakotka.com; https://www.rostock-port.de; www.portoftallinn.com; www.portofventspils.lv; www.cmport.com; www.harboursreview.com/port-lubeck; https://www.espo.be/media/Annual\%20Report\%202016-2017-FINAL.pdf; https://vuosikertomus2017.portofhelsinki.fi/en/the-business-grew-strongly/; www.portgdansk.pl; www.port.gdynia.pl; www.portszczecin.pl).

W obrotach towarowych portów RMB w 2017 roku przeważały ładunki masowe płynne $(37,82 \%)$ oraz ładunki drobnicowe $(34,28 \%)$, natomiast ładunki masowe suche stanowiły ok. $27,9 \%$ wszystkich przeładowanych. Najwięcej paliw obsłużono w portach rosyjskich Ust Łudze oraz Primorsku, a także w portach skandynawskich Skoeldviku, Goeteborgu i Brofjorden, port w Gdańsku (w tym rankingu) zajął 6. pozycję. Najwięcej ładunków masowych suchych (w 2017 roku) przeładowały porty w Ust Łudze, Rydze, Kłajpedzie, Gdańsku i St. Petersburgu, a zespół portów w Szczecinie i Świnoujściu zajął w tym rankingu 6. pozycję, natomiast najwięcej ładunków drobnicowych obsłużyły porty w St. Petersburgu, Gdańsku, Goeteborgu, Lubece oraz Kłajpedzie. W 2017 roku w 20 największych bałtyckich portach obsłużono łącznie ok. 7,7 mln TEU. Najwięcej kontenerów obsłużyły porty w St. Petersburgu, Gdańsku, Gdyni, HaminaKotce i Goeteborgu. Ważną częścią przewozów bałtyckich są przewozy pasażerów (zarówno promami, jak i statkami wycieczkowymi). W portach RMB w 2017 roku obsłużono ok. $113 \mathrm{mln}$ pasażerów (w 2005 roku było ich ok. $60 \mathrm{mln}$ ). Największymi portami pasażerskimi są: Helsinki (12,7 mln os.), Sztokholm (11,4 mln os.), Tallin (10,6 mln os.), Rostok i Turku. Okazuje się, że 10 największych portów pasażerskich na Bałtyku obsłużyło w 2017 roku ok. 47\% wszystkich pasażerów obsłużonych w portach bałtyckich (Baltic yearbook 2017/2018, 2018, s. 15-28).

Wskaźnik udziału portu w Gdańsku w bałtyckim rynku usług portowych (uwzględniając przeładunki ogółem) w 2017 roku wyniósł ok. 4,46\%, zaś dla portów w Szczecinie i Świnoujściu kształtował się na poziomie ok. 2,79\%, a dla portu w Gdyni na poziomie ok. 2,33\% (udziały polskich portów wśród 20 największych 
portów bałtyckich wyniosły: Gdańska ok. 6,59\%, Szczecina i Świnoujścia ok. 4,12\%, zaś Gdyni ok. 3,44\%). W 2017 roku bałtyckie porty obsłużyły łącznie ok. 343,953 mln ton ładunków płynnych. Wskaźnik udziału portu w Gdańsku $\mathrm{w}$ bałtyckim rynku usług portowych na rzecz ładunków płynnych wyniósł ok. 3,83\%, dla portów w Szczecinie i Świnoujściu kształtował się na poziomie 0,98\%, zaś dla portu w Gdyni na poziomie 0,53\% (20 największych portów RMB przeładowało łącznie ok. $80 \%$ tych ładunków, tj. 274,6648 mln ton, wskaźnik udziału gdańskiego portu wśród tych 20 największych portów wyniósł 4,79\%, portów w Szczecinie i Świnoujściu 1,23\%, zaś portu w Gdyni 0,66\%). W 2017 roku porty RMB obsłużyły łącznie ok. 253,609 mln ton ładunków masowych suchych. Wskaźnik udziału portu w Gdańsku w bałtyckim rynku usług portowych na rzecz ładunków masowych suchych wyniósł ok. 3,7\%, portów w Szczecinie i Świnoujściu 3,62\%, zaś portu w Gdyni 2,74\% (20 największych portów RMB przeładowało łącznie ok. 60,47\% tych ładunków, tj. 153,345 mln ton, wskaźnik udziału gdańskiego portu wśród tych 20 największych portów wyniósł 6,13\%, portów w Szczecinie i Świnoujściu 5,98\%, zaś portu w Gdyni 4,53\%). W 2017 roku bałtyckie porty morskie przeładowały łącznie ok. 311,688 mln ton ładunków drobnicowych. Wskaźnik udziału portu w Gdańsku w bałtyckim rynku usług portowych na rzecz ładunków drobnicowych wyniósł ok. 5,79\%, portów w Szczecinie i Świnoujściu 4,13\%, zaś portu w Gdyni ok. 4\% (20 największych portów RMB przeładowało łącznie ok. 60,38\% tych ładunków, tj. 188,206 mln ton, wskaźnik udziału gdańskiego portu wśród tych 20 największych portów wyniósł 9,59\%, portów w Szczecinie i Świnoujściu 6,84\%, zaś portu w Gdyni 6,62\%). W 2017 roku porty RMB obsługiwały także ładunki skonteneryzowane (łącznie ok. 9,95 mln TEU). Wskaźnik udziału portu w Gdańsku w bałtyckim rynku usług portowych na rzecz ładunków skonteneryzowanych wyniósł ok. 16,02\%, portu w Gdyni ok. 7,14\%, zaś portów w Szczecinie i Świnoujściu 0,94\% (20 największych portów RMB przeładowało łącznie ok. 78,27\% tych ładunków, tj. 7,788154 mln TEU, wskaźnik udziału gdańskiego portu wśród tych 20 największych portów wyniósł 20,46\%, portu w Gdyni 9,13\%, zaś portów w Szczecinie i Świnoujściu $1,2 \%)$.

Z powodu położenia geograficznego najważniejszymi zagranicznymi konkurentami polskich portów morskich są dość blisko zlokalizowane porty południowego wybrzeża Bałtyku: Lubeka, Rostok, Kaliningrad i Kłajpeda. Jednakże w zakresie obsługi niektórych grup ładunków do konkurentów polskich portów są zaliczane także: Ryga, Tallin, Primorsk, Ust Ługa, Ventspils, Butynga (dla ładunków masowych płynnych), Hamburg, Bremerhaven, Rotterdam (dla ładunków skonteneryzowanych) oraz Sassnitz dla ładunków ro-ro. Konkurencja odbywa się także pomiędzy portowymi terminalami wewnątrz poszczególnych portów, jak i pomiędzy portami krajowymi (dotyczy zarówno przyciagania gestorów ładunków, armatorów, pasażerów, jak i inwestorów) (Rucińska, 2015, s. 311-312). 
W związku z rozwojem międzynarodowych logistycznych łańcuchów dostaw i dążeniem przewoźników i załadowców do optymalizacji kosztów, a także wraz z rozwojem korytarza Bałtyk-Adriatyk w transeuropejskiej bazowej sieci transportowej TEN-T okazuje się, że konkurentami polskich portów mogą być też porty północnego wybrzeża Adriatyku, tj. Ravenna, Wenecja, Triest, Koper i Rijeka (stowarzyszone w North Adriatic Ports Association - NAPA). Mogą być w nich obsługiwane ładunki przywożone statkami z Azji, które następnie drogą lądową mogą być wysyłane na północ, w kierunku Polski, z pominięciem polskich portów morskich.

\section{Zakończenie}

Największe polskie porty są portami uniwersalnymi, jednak obsługa ładunków odbywa się $\mathrm{w}$ nich $\mathrm{w}$ wyspecjalizowanych terminalach dedykowanych poszczególnym rodzajom ładunków, co gwarantuje wysoką jakość usług. A trzeba podkreślić, że jakość usług oferowanych w polskich portach jest na ogół bardzo wysoko oceniana przez usługobiorców, ponieważ porty te dysponują nowoczesnym potencjałem usługowym i mogą obsługiwać statki i ładunki przez 24 godziny na dobę przez 7 dni $w$ tygodniu (są też portami niezamarzającymi, co na Bałtyku jest ważnym czynnikiem konkurencyjności). Parametry infra- i suprastruktury portowej w Gdańsku już obecnie umożliwiają obsługę największych statków, jakie mogą wpłynąć na Bałtyk, zaś realizacja ambitnych planów inwestycyjnych pozostałych portów (zwłaszcza w zakresie pogłębiania akwatorium) umożliwi im przyjmowanie coraz większych jednostek (Klimek, Rolbiecki, 2017, s. $88-89$ ).

Podsumowując dotychczasowe rozważania, należy stwierdzić, że w związ$\mathrm{ku}$ z rozwojem globalizacji światowej gospodarki, wzrostem wolumenu handlu międzynarodowego, $\mathrm{w}$ tym morskiego (w 2017 roku wolumen handlu morskiego na świecie wyniósł 10,7 mld ton, co oznacza, że był o 78,84\% wyższy niż w 2000 roku i zarazem najwyższy w historii) (UNCTAD, 2018, s. 5), rozwojem globalnych logistycznych łańcuchów dostaw, procesami integracyjnymi w światowym handlu i transporcie, ciagłym rozwojem na wielką skalę konteneryzacji i multimodalizmu zmieniają się warunki funkcjonowania transportu morskiego na całym świecie, wzmacnia się rola i znaczenie portów oraz żeglugi morskiej wewnątrz rozwijającego się globalnego systemu transportowego, a jednocześnie umacnia się pozycja sektora TSL (transportowo-spedycyjno-logistycznego) na rynkach usług. Ważnym przejawem takich zmian jest wzrost konkurencji pomiędzy lądowo-morskimi łańcuchami transportowymi, który zmusza podmioty transportu morskiego do podnoszenia jakości świadczonych usług, a także narzuca im konieczność stosowania określonych standardów rozwiązań w sferze działalności gospodarczej, zarządzania i ochrony środowiska naturalnego. 
Ostatnia dekada XX i początek XXI wieku były dla światowego transportu morskiego okresem intensywnych zmian. Dotyczy to także Polski. Zmiany polityczne i gospodarcze, zwłaszcza odejście od centralnego sterowania i wprowadzenie polskiej gospodarki na tory gospodarki rynkowej, spowodowały, że zasadniczo zmieniły się warunki funkcjonowania portów morskich (zarówno postrzeganych jako ośrodki podaży usług portowych, na terenach których funkcjonują niekiedy bardzo liczne podmioty sfery eksploatacji oraz podmioty zarządzające infrastrukturą i terenami w granicach administracyjnych portów, jak i poszczególne przedsiębiorstwa świadczące różnorodne usługi portowe), a w szczególności musiały one stawić czoła intensywnej międzygałęziowej i wewnątrzgałęziowej konkurencji (która z jednej strony prowadzi do korzystnych zmian jakościowych, ale także powoduje, że funkcjonowanie na rynkach, zwłaszcza międzynarodowych, utrzymanie i umacnianie własnych pozycji rynkowych i konkurencyjnych, a także pozyskiwanie ładunków staje się coraz trudniejsze), postępowi technicznemu i technologicznemu i wyzwaniom związanym ze zrównoważonym rozwojem.

Ogromne szanse na zmiany jakościowe, przede wszystkim związane z możliwościami poprawy stanu infrastruktury w portach i zapewniającej dostęp do portów, uzyskały polskie porty dzięki funduszom Unii Europejskiej. Umiejętne aplikowanie i korzystanie $\mathrm{z}$ tych środków finansowych przyczyniło się i nadal przyczynia do odtworzenia wysoko zdekapitalizowanych, zaniedbywanych przez dziesięciolecia, obiektów infrastrukturalnych (w 2004 roku stopień fizycznego zużycia infrastruktury $w$ największych polskich portach wynosił ponad $60 \%$, obecnie kształtuje się na poziomie ok. 50\%) (Naczelna Izba Kontroli [NIK], 2015, s. 18).

Polskie porty, zwłaszcza te o podstawowym znaczeniu dla gospodarki, intensywnie zabiegają o podnoszenie swoich pozycji konkurencyjnych w regionie bałtyckim i w Europie (zlokalizowany w gdańskim porcie, uruchomiony w 2007 roku, największy w Polsce i na Bałtyku terminal kontenerowy - Deepwater Container Terminal Gdańsk - w 2017 roku zajął 16. pozycję wśród europejskich terminali kontenerowych, przeładowując prawie 1,6 mln TEU) (Rynek Infrastruktury, 2018). Niewątpliwie realizacja ambitnych planów inwestycyjnych tych portów przyczyni się do podniesienia ich zdolności do konkurowania nie tylko na krajowych i bałtyckich, ale także na europejskich rynkach usług portowych. Trzeba jednak podkreślić, że sytuacja na rynkach usług portowych, na których konkurują polskie porty, ze względu na charakter tych rynków i globalny wymiar transportu morskiego, w znacznym stopniu jest uzależniona od szybko zmieniającego się otoczenia, w którym funkcjonują. 


\section{Bibliografia}

1. Baltic yearbook 2017/2018 (2018). Baltic Transport Journal, 4.

2. GUS (2018a). Rocznik statystyczny gospodarki morskiej 2017. Warszawa-Szczecin: Urząd Statystyczny w Szczecinie.

3. GUS (2018b), Gospodarka morska w Polsce w 2017 r. Warszawa: Główny Urząd Statystyczny, https://stat.gov.pl/obszary-tematyczne/transport-i-lacznosc/transport/ gospodarka-morska-w-polsce-w-2017-roku,7,15.html

4. https://vuosikertomus2017.portofhelsinki.fi/en/the-business-grew-strongly/ (dostęp: 11.12.2018).

5. https://www.espo.be/media/Annual\%20Report\%202016-2017-FINAL.pdf (dostęp: 9.12.2018).

6. https://www.rostock-port.de (dostęp: 9.12.2018).

7. Klimek H. (2018), Ambitne plany inwestycyjne polskich portów morskich. Namiary na Morze i Handel, 2.

8. Klimek H., Rolbiecki R.(2017) Funkcja transportowa największych polskich portów morskich, Zeszyty Naukowe Uniwersytetu Gdańskiego Ekonomika Transportu i Logistyka, 63.

9. MGMiŻŚ (2017). Program rozwoju polskich portów morskich do roku 2020 (z perspektywa do 2030 roku). Warszawa: Ministerstwo Gospodarki Morskiej i Żeglugi Śródlądowej.

10. Międzyresortowy Zespół do spraw Polityki Morskiej Rzeczypospolitej Polskiej (2015). Polityka morska Rzeczypospolitej Polskiej do roku 2020 (z perspektywa do 2030 roku). Warszawa: Międzyresortowy Zespół do spraw Polityki Morskiej Rzeczypospolitej Polskiej.

11. MTBiGM (2013). Program rozwoju polskich portów morskich do roku 2020 (z perspektywa do 2030 roku). Warszawa: Ministerstwo Transportu, Budownictwa i Gospodarki Morskiej.

12. NIK (2015). Gospodarki finansowa i inwestycyjna portów morskich o podstawowym znaczeniu dla gospodarki narodowej, Warszawa: Naczelna Izba Kontroli.

13. Rucińska D. (red.) (2015). Rynek ustug transportowych w Polsce. Warszawa: PWE.

14. Rynek Infrastruktury (2018). $9 \mathrm{mln}$ kontenerów przeładowanych przez DCT Gdańsk, www.rynekinfrastruktury.pl (dostęp: 28.06.2018).

15. Uchwała Nr 6 Rady Ministrów z dnia 22 stycznia 2013 r. w sprawie Strategii Rozwoju Transportu do 2020 r. (z perspektywa do 2030 r.), M.P. poz. 75.

16. Uchwała nr 8 Rady Ministrów z dnia 14 lutego 2017 r. w sprawie przyjęcia Strategii na rzecz Odpowiedzialnego Rozwoju do roku 2020 (z perspektywa do 2030 r.), M.P. poz. 260.

17. UNCTAD (2018). Review of Maritime Transport 2018. Nowy Jork, Genewa: UNCTAD.

18. Ustawa z dnia 20 grudnia 1996 r. o portach i przystaniach morskich, Dz. U. 2010, nr 33, poz. 179 , z późn. zm.

19. www.cmport.com (dostęp: 9.12.2018).

20. www.haminakotka.com (dostęp: 9.12.2018).

21. www.harboursreview.com/port-lubeck (dostęp: 9.12.2018).

22. www.port.gdynia.pl (dostęp: 9.12.2018).

23. www.portgdansk.pl (dostęp: 9.12.2018). 
24. www.portoftallinn.com (dostęp: 9.12.2018).

25. www.portofventspils.lv (dostęp: 9.12.2018).

26. www.portszczecin.p (dostęp: 9.12.2018).

\section{POLISH SEAPORTS ON THE PORT SERVICES MARKETS}

\section{Summary}

Polish seaports operate on international port services markets which are characterised by intense competition. In contested port hinterland, they compete for cargo and carriers' interest among themselves, with foreign ports (mainly those located on the North Sea coasts and the southern coast of the Baltic Sea), as well as with land transport (including transcontinental connections). This competition undoubtedly contributes to undertaking activities to develop their production potential, to extend their offer of services, to improve the quality of their services, as well as to implement solutions that aim to attract not only shippers and carriers, but also investors. The major Polish seaports are currently among the largest in the Baltic Sea region. The aim of this article is to present their competitive positions on the domestic and the Baltic Sea markets of port services. The goal of the implementation of the strategies adopted by these ports several years ago is to contribute to the improvement of their ability to compete, as well as their competitive positions.

Keywords: port services market, seaport competitiveness, market share.

JEL Classification: M210 
